\section{RHYTHMIC UNITS AND TONAL VARIATION IN THAI}

\section{Phanintra Teeranon ${ }^{1}$}

\section{Abstract}

This study investigates whether rhythmic units influence tonal realizations in Thai connected speech. The informants are three female radio announcers, 26 and 30 years of age. Their speech was recorded prior to informing them about the study. They were then asked to read two sets of tone checklists: unchecked and checked syllables. For each tone, five tokens were selected for each following context: (1) a salient syllable in one-syllable, two-syllable, and threesyllable rhythmic units, and (2) a weak syllable in a two-syllable rhythmic unit, the first weak syllable and the second weak syllable in a three-syllable rhythmic unit. The fundamental frequency values of all of the tokens were analyzed and recorded using WINCECIL and EXCEL. Line graphs were drawn to show the realization of different tones in different contexts. WINPSY 0602 2000 (School of Psychology, University of New South Wales) was used to analyze whether the variation between tone shapes is statistically significant.

The different are statistically significant when the tonal characteristics of the salient (S1, S2, S3) and of the weak (w2, w3/1, w3/2) are compared with the ones of the citation form (CF). However, the F0 value of different types of stressed

\footnotetext{
${ }^{1} \mathrm{Ph}$.D. Candidates, Department of Linguistics, Faculty of Arts, Chulalongkorn Univetsity, Bangkok, Thailand.
}

or salient syl-lables do not differ from each other in a significant way for level tones and so of unstressed or weak syllables. These findings suggest that in studying tonal variation, rhythm only influences contour tones.

\section{Introduction}

Rhythm exists in every language. Whenever we speak, there's always rhythm. Though it is said that, sometimes, rhythm is what we feel, it is defined as timing and interval time of syllables. Syllables, therefore, are the fundamental unit of rhythm. And syllables are also important as members of each rhythmic unit. ${ }^{2}$ Each rhythmic unit cannot be

${ }^{2}$ Rhythmic Unit is the fundamental unit of rhythm known as the foot. Halliday (1970, p.1) said "The foot, therefore, is like the 'bar' in music; and a spoken sentence consists of a succession of feet, in the same way as a piece of music consists of a succession of bars.

Each foot, in turn, consists of a number of syllables, one or more; and the first syllable in a foot is always salient. The salient syllable carries the beat. 'Salient' can be thought of as meaning 'stressed'; but we shall use the term 'salient', suggested by Professor David Abercrombie, in preference to 'stressed' because 'stressed' has been made to mean so many different things that its use here could be confusing.

Each foot normally consists either of one salient syllable alone or of one salient syllable followed by one or more non-salient, or weak syllables. Thus, again like the bar in music, the foot always begins with a beat. But a musical bar may also begin with a rest, a silent beat; and this explains the use of the word 'normally' just above, because the same is true of the foot in English speech. A foot may begin with a silent beat without the rhythm becoming disrupted or lost." 
equal in time, but it is relatively equal in time. For temporal school ${ }^{3}$, in each rhythmic unit, first syllables are always full syllables (or 'stressed') with or without reduced syllables (or 'unstressed') in the next position. For Thai, as a tonal language, the syllable is important both as a member of the rhythmic unit, and also as a carrier of pitch, which is significant in distinguishing the meaning in word level. If full or reduced syllables do affect tones, we expect, therefore that the rhythmic unit should also influence the tone.

For examples: Thai sentences;

| mê: | ná:m |yŕ? | can |---1

|^ mê: | ná:m | ý̛?| can | ----2

The first and the second sentences have 4 rhythmic units, but different meaning. The first sentence means 'Mother, there's a lot of water.' the second sentence means 'There are so many rivers.' The first foot of the first sentence consists of only one syllable: a salient syllable. But the first foot of the second sentence consists of two syllables; a salient syllable that is a silent beat $\left({ }^{\wedge}\right)$ or pause, and a weak syllable.

${ }^{3}$ Speech rhythm scholars are divided into two schools. The first one is the Traditional School (Abercrombie, 1967); the purpose was to use rhythm to make reading poems beautiful and enchanted. For this school, in each rhythmic unit, both stressed and unstressed syllable could be the first syllable in each rhythmic unit. The second one is the Temporal School. David Abercrombie, who was influenced by psychologists, is the leader. This school uses the musical principle that every musical bar must start with a beat or pause, followed by none or some other notes. Isochronousity of musical bar has been adapted to the concept of isochronous speech. The subtypes of rhythm in speech found up to present are three: syllable-timed rhythm such as French, stressedtimed rhythm such as Thai and English, and mora-timed rhythm such as Japanese (Laver, 1994).
Previous studies revealed that rhythm affected syllable length, in Thai, both in normal and esophageal speech (Luangthongkum, 1977, 1983; Gandour et al., 1986). Later, it is said to have effect on Thai tones, but in the contexts of stressed and unstressed syllables (Hiranburana, 1972; Potisuk et al 1994, 1996; Tingsabadh\&Deeprasert, 1997 and Pinijarom, 1990). Recently, speaking rate, which determines speech rhythm was also found to influence Thai tones (Gandour et al., 1999). As mentioned earlier, in connected speech, all kinds of syllables-stressed and unstressed-are superimposed by rhythm. The previous research, though concerned with connected speech, however, has not yet dealt with rhythmic units, which are the fundamental units of rhythm. Thus, this study hypothesizes that rhythm affects Thai tones and it investigates these effects. This study collected data without informing the informants about the study in order to obtain near natural spontaneous speech. This is a bit different from previous studies, which obtained the data from reading passages (Tingsabadh \& Deeprasert; 1997, Pinijarom; 1990, etc.) or sentence frames (Gandour et al., 1999).

\section{Method}

\section{Subjects}

The informants are 3 female Thai radio announcers, between 26 and 30 years old. They have run a conversational style program at 101.5 Chulalongkorn University radio station. 


\section{Speech Materials}

Spontaneous speech was obtained from the informants without giving notice about the purpose of this study. After collecting the data, they were then asked to pronounce 2 tone checklist containing 2 sets of syllables: unchecked syllables and checked syllables which were subgrouped into long checked syllables, short checked syllables ending with final stops and short checked syllables ending with final glottal stop. ${ }^{4}$ These data represented the citation forms (CF). ${ }^{5}$ The structure of the rhythmic units ${ }^{6}$ used in this study was then set as in Table 1 in Appendix:

As shown in Table 1 (see the Appendix), a one-syllable rhythmic unit consists of one salient syllable or one pause $\left(\mathrm{S}\right.$ or $\left.{ }^{\wedge}\right)$.A two-syllable rhythmic unit consists of one salient syllable and one weak syllable or one pause (also called silent stress) and one weak syllable ( $\mathrm{Sw}$ or ${ }^{\wedge} \mathrm{w}$ ). A three-syllable rhythmic unit consists of one salient syllable and two weak syllables or one pause and two weak syllables (Sww or ${ }^{\wedge}$ ww). In this

${ }^{4}$ In citation form, short checked syllables with final glottal stop have been treated as short checked syllables with final stops following Tumtavitikul (1992), who classifies short checked syllables ending with a final glottal stop as the coda of short checked syllables, in the same group with short checked syllables ending with stops.

5 The tokens in citation forms are (1) unchecked syllables: kha:, khà:, khâ:, khá:, khă:, and (2) checked syllables: khà:t, khâ:t, khàt, khât.

${ }^{6}$ Luangthongkum $(1977,1983)$ found that those three rhythmic structures (one syllable rhythmic unit, two syllable rhythmic unit and three syllable rhythmic unit) occur in most Thai speech, $60.99 \%, 20.57 \%, 13.47 \%$ respectively. study, those three types of rhythmic units in Table 1 will be referred to as follows: $\mathrm{S} 1$ for salient syllable in a one-syllable rhythmic unit, S2 for salient syllable in a two-syllable rhythmic unit, S3 for salient syllable in a three-syllable rhythmic unit, w2 for the weak syllable in a two-syllable rhythmic unit, w3/1 for the first weak syllable in a a three-syllable rhythmic unit, and w $3 / 2$ for the second weak syllable in a three-syllable rhythmic unit.

To study the effect of rhythm on Thai tones, the series of fundamental frequency (or tone shape) in the following contexts were compared:

(1) salient syllable in a one-syllable rhythmic unit and citation form (S1 CF); salient syllable in a two-syllable rhythmic unit and citation form (S2 CF); salient syllable in a three-syllable rhythmic unit and citation form (S3 CF); weak syllable in a two-syllable rhythmic unit and citation form (w2 CF); the first weak syllable in a three-syllable rhythmic unit and citation form (w3/1 CF); and the second weak syllable in a three-syllable rhythmic unit and citation form (w3/2 CF).

(2) salient syllable in a one-syllable rhythmic unit and salient syllable in a two-syllable rhythmic unit (S1 S2); salient syllable in a one -syllable rhythmic unit and salient syllable in a threesyllable rhythmic unit (S1 S3); and salient syllable in a two-syllable rhythmic unit and salient syllable in a three-syllable rhythmic unit (S2 S3).

(3) weak syllable in a two-syllable rhythmic unit and the first weak syllable in a three-syllable rhythmic unit (w2 w3/1); weak syllable in two-syllable rhythmic unit and the second weak syllable in a 
three-syllable rhythmic unit (w2 w3/2); and the first weak syllable in a threesyllable rhythmic unit and the second weak syllable in a three-syllable rhythmic unit (w2 w3/1).

The overall 1,301 tokens were studied using WINCECIL. Line graphs were then drawn using Excels.

By using WINPSY 0602 2000, statistic method called Trend analysis was used to test the differences of tone shapes in those contexts above. Three characteristics of tone shapes were tested; linear (straight line), quadratic (bend curve) and pitch height. It is found that differences occur when; (1) all characteristics (linear, quadratic and height value) are statistically significant, (2) two characteristics (linear \& quadratic, linear \& height value and quadratic \& height value) are statistically significant, and (3) only one characteristics (linear, quadratic or height value) is statistically significant. It is also interesting even when F-value $^{7}$ is near critical value since this means the possibility of significant difference, if more data are collected. If there is no statistic significant, rhythm has no effect on the tones.

\section{Results}

\section{Tonal realization in salient and weak syllables in each rhythmic unit compared to the citation forms}

${ }^{7} \mathrm{~F}$-value, about 4.60 is the critical value. If the obtained test F-value is less than 4.60, we can infer that there is no significant difference in tone shape, direction and height between contexts. But if the F-value from calculation is higher than 4.60 , we can infer that there is a significantly different tone shape, direction or height between contexts.
In comparing between the salient and the weak syllable in each rhythmic unit (from now on called the salient and the weak) to the citation forms (S1 CF, S2 CF, S3 CF, w2 CF, w3/1 CF, w3/ $2 \sim \mathrm{CF}$ ), it was found that there was variation in tonal realizations. See Figure 1 and Figure $2^{8}$ in the Appendix.

The differences found when comparing $\mathrm{S} 1, \mathrm{~S} 2$ and S3 to CF, respectively, varied. The difference between S3 CF is greater than the difference between $\mathrm{S} 1 \sim \mathrm{CF}$ and $\mathrm{S} 2 \sim \mathrm{CF}$.

When comparing S1 CF, one type of characteristic of tone shapes was found different. When comparing $\mathrm{S} 2 \sim \mathrm{CF}$, one to two types of characteristic of tone shapes was found different. When comparing S3 $\sim \mathrm{CF}$, one to three types of characteristic of tone shapes was found different.

It is to be noted that in falling tone three types of characteristic differ.

The differences found with the comparison of $w 2, w 3 / 1$ and $w 3 / 2$ to CF, respectively, varied See Figure 1 and Figure 2 in the Appendix. The difference between w3/2 CF is greater than the difference between $\mathrm{w} 2 \sim \mathrm{CF}$ and $\mathrm{w} 3 / 1 \sim \mathrm{CF}$.

In the context of the comparison between $w 3 / 2 \sim \mathrm{CF}$, one to three types of characteristic of tone shapes was found different in both level and contour tones. While one to two types of characteristic of tone shapes was found different when comparing $w 2 \sim \mathrm{CF}$ and $\mathrm{w} 3 / 1 \sim \mathrm{CF}$.

\footnotetext{
${ }^{8}$ As in Figure 1 and Figure 2, rhythmic unit in citation form, the salient and the weak show parallel variation.
} 
Again, in falling tone, three types of characteristic differ.

And in high tone, the tonal realizations in quadratic shape differ instead of linear shape as expected in all level tones.

The greater difference when comparing S3 CF and $w 3 / 2 \sim C F$ is due to the duration of S3 and w3/2 that differ much from CF than the rest contexts (see Table 3 ). In the context of citation forms, syllables have the longest duration. Of the shorter duration are the syllables in the salient, and the shortest duration is in the weak.

\section{Tonal realization of the salient and the salient; the weak and the weak in different rhythmic unit}

The differences found when comparing (1) S1 S2, S1 S3 and S2 S3, and (2) w2 $\sim$ w $3 / 1$, w2 w $3 / 2$ and w $3 / 1 \sim$ w $3 / 2$ are shown in Figure 1 and 2 in the Appendix.

However, the statistic results show that the differences found when comparing between S1, S2 and S3 (S1 S2, S1 S3 and $\mathrm{S} 2 \sim \mathrm{S} 3$ ) are not varied which is similar to the comparison between w2, w3/ 1 and $w 3 / 2$ (w2 w3/1, w2 w3/2 and w3/1 w3/2). See Table 4 and 5 in the Appendix. In all contexts, one to two types of characteristic were found different.

Similarly, the high tone realization is similar to the result in I. noted above that its shape varied significantly in quadratic characteristics like contour tone.

As for the rising tone, the result agrees with Luksaneeyanawin's (1983), that it is still keeps rising shape in most contexts.

\section{Discussion}

From the result noted above, high tone seems to be the most distinctive. Phonetically, previous research found that high tone was realized as high level. However, this research found that in the context of citation forms (see Figure 1 in the Appendix), high tone has mid-rising shape. These findings support the observation of Abramson (1979), Tumtavitikul (1992) and Potisuk et al. (1994) and Chuwarahawong (2000) that the Thai high tone has rising contour. Teeranon (2002) has found that within 90 years between 1911 and 2000 , high tone has change a from high falling to mid-rising. Therefore, Standard Thai tones might have two level tones, the mid and the low. The other three tones are contour tones: high, falling and rising. This is not yet the fact; the question is left to further study.

Tonal realization of the salient in onesyllable rhythmic unit is very similar to tonal realization of the citation forms. While tonal realization of the salient syllable in other structures of the rhythmic unit is less similar to tonal realization of the citation forms. Since the salient syllable in a one-syllable rhythmic unit takes more time in production contrast to the salient in other rhythmic units. For tonal realization of the weak syllable in rhythmic unit, the realization of the second weak in three-syllable rhythmic unit physically remarkably differs from tonal realization in the citation forms. (See Figures 1 and 2 in the Appendix) Though the time used in producing the second weak in three-syllable rhythmic unit is different from the first weak in three-syllable rhythmic unit. (See table 3 in the Appendix) It can be inferred that the number and position of the weak syllable does not destroy in- 
herent physical of tonal realization.

The result agrees with Luangthongkum's (1977, 1983); she mentioned that real time and the duration ratio of rhythmic unit must be treated in different dimension. From Figure 1, tone shapes of the first and the second weak syllables in a three-syllable rhythmic unit are different, though, they have the same duration ratio of $3 /{ }_{4}$. See Table 3 in the Appendix.

The results also agree with Potisuk et al (1994) i.e, tonal characteristics of unstressed syllables are clearly different form stressed syllables. This can be inferred that it may not be necessary to study tonal realizations by taking rhythm into account.

\section{Conclusion}

In the presentation of results, the five Standard Thai tones were divided into two groups: level tones (mid, low, and high) and contour tones (falling and rising). The study finds that in the case of the salient syllables, rhythmic units significantly influence the tonal realizations of contour tones in most contexts, but they do not have the same effect on level tones. In the case of the weak syllables, rhythmic units influence tonal realizations only in some contexts for both level and contour tones. However, there are a few interesting exceptions in both the salient and the weak syllables. Tonal realizations of the high tone in short checked syllables differ significantly when occurring in two- and threesyllable rhythmic units. The falling tone differs markedly from the rising tone. While the rhythmic units significantly influence the variation of the falling tone in unchecked syllables in most contexts, they have much less influence on the rising tones.

\section{References}

Abercrombie, David. 1967. Element of General Phonetics. Edinburgh: Edinburgh University Press.

Abramson, Arthur S. 1979. The Coarticulation of Tones: An Acoustic Study of Thai. In Studies in Tai and Mon-Khmer Phonetics and Phonology in Honour of Eugenie J.A. Henderson, ed. by L-Thongkum, T.,Kullavanijaya, P., Panupong, V., and Tingsabadh, K., pp.1-9. Bangkok: Chulalongkorn University Press.

Chuwarahawong, Wilailuck. 2000. Tones in Bangkok Thai spoken by the Thai, the Chao Zhou and the Sikhs (วรรณยุกต์ภาษาไทยกรุงเทพบ ที่พูดโดยคนไทย คนแต่จิจว และคนริกช์. Unpublished M.A. thesis, Chulalongkorn University.)

Gandour, J., Siripong Potisuk, Suvit pongpisit, Sumalee Dechongkit. 1991. Inter- and Intraspeaker Variability in Fundamental Frequency of Thai Tones. Speech Communication 10, pp. 355-372.

Gandour, J. Bernd Weinberg and Soranee Holasuit Petty. 1986. Rhythm in Thai Esophageal Speech. Journal of Speech and Hearing Research 29, pp. 563-568.

Gandour, J., Siripong Potisuk, Sumalee Dechongkit. 1994. Tonal Coarticulation in Thai. Journal of Phonetics 22, pp. 477-492.

Gandour, J., A. Tumtavitikul, N. Sattamnuwong. 1999. Effects of Speaking Rate on Thai Tones. Phonetica 56, pp.163-134. 
Halliday, M.A.K. 1970. A Course in Spoken English: Intonation. London: Oxford University Press.

Hiranburana, S. 1972. Changes in Pitch Contours of Unaccented Syllables. In Tai Phonetics and Phonology, ed. by J. G. Harris \& R. B. Noss, pp.23-27. Bangkok: Central Institute of English Language.

Laver, John. 1994. Principles of Phonetics. Cambridge: University Press.

Luangthongkum, Theraphan. 1977. Rhythm in Standard Thai. Unpublished doctoral dissertation. University of Edinburgh.

Luangthongkum, Theraphan. 1983. Rhythm in Thai from Another View Point. Pasaa 6, pp. 144-158.

Luksaneeyanawin, Sudaporn. 1983. Intonation in Thai. Unpublished doctoral dissertation. University of Edinburgh.

Pinijarom, R. 1991. Acoustic Characteristics of Unstressed Syllables in Thai. Unpublished Master's Thesis. Chulalongkorn University.

Potisuk, Siripong, Jack Gandour, Mary Harper. 1994. F0 Correlates of Stess in Thai. Linguistics of Tibeto-Burman Area 17, pp. 1-27.

Potisuk, Siripong, Jack Gandour, Mary Harper. 1996. Acoustic Correlates of Stess in Thai, Phonetica 53, pp. 200-220.

Teeranon, Phanintra. 2002. The Changes of High Tone in Standard Thai

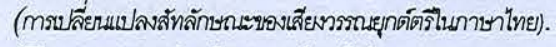
(To appear in Journal of Arts, Silapakorn University)
Tingsabadh, K. and D. Deeprasert. 1997. Tones in Standard Thai Connected Speech. In Southeast Asian Linguistics Studies in Honour of Vichin Panupong, ed. by A.S. Abramson. pp.297-370. Bangkok: Chulalongkorn University Press.

Tumtavitikul, A. 1992. Consonant Onsets and Tones in Thai. Unpublished doctoral dissertation. University of Texas at Austin.

\section{Acknowledgement}

This paper is based on my unpublished MA thesis: "Rhythmic Unit and Tonal Variation in Thai Connected Speech", Department of Linguistics, Faculty of Arts, Chulalongkorn University. I would like to express my gratitude to my thesis advisor, M.R. Kalaya Tingsabadh for her comments, patient and kindness. I am indebted Pranee Kullavanijaya and Theraphan L-thongkum, for their valuable comments.

I also would like to thank Sudaporn Luksaneeyanawin and Arthur S. Abramson for their suggestions. Finally, I would like to acknowledge the grant given by the Institute of Thai Studies, Chulalongkorn University for the presentation of this paper at the 8th International Conference on Thai Studies at Nakorn Phanom. 
Rhythmic Units and Tonal Variation in Thai

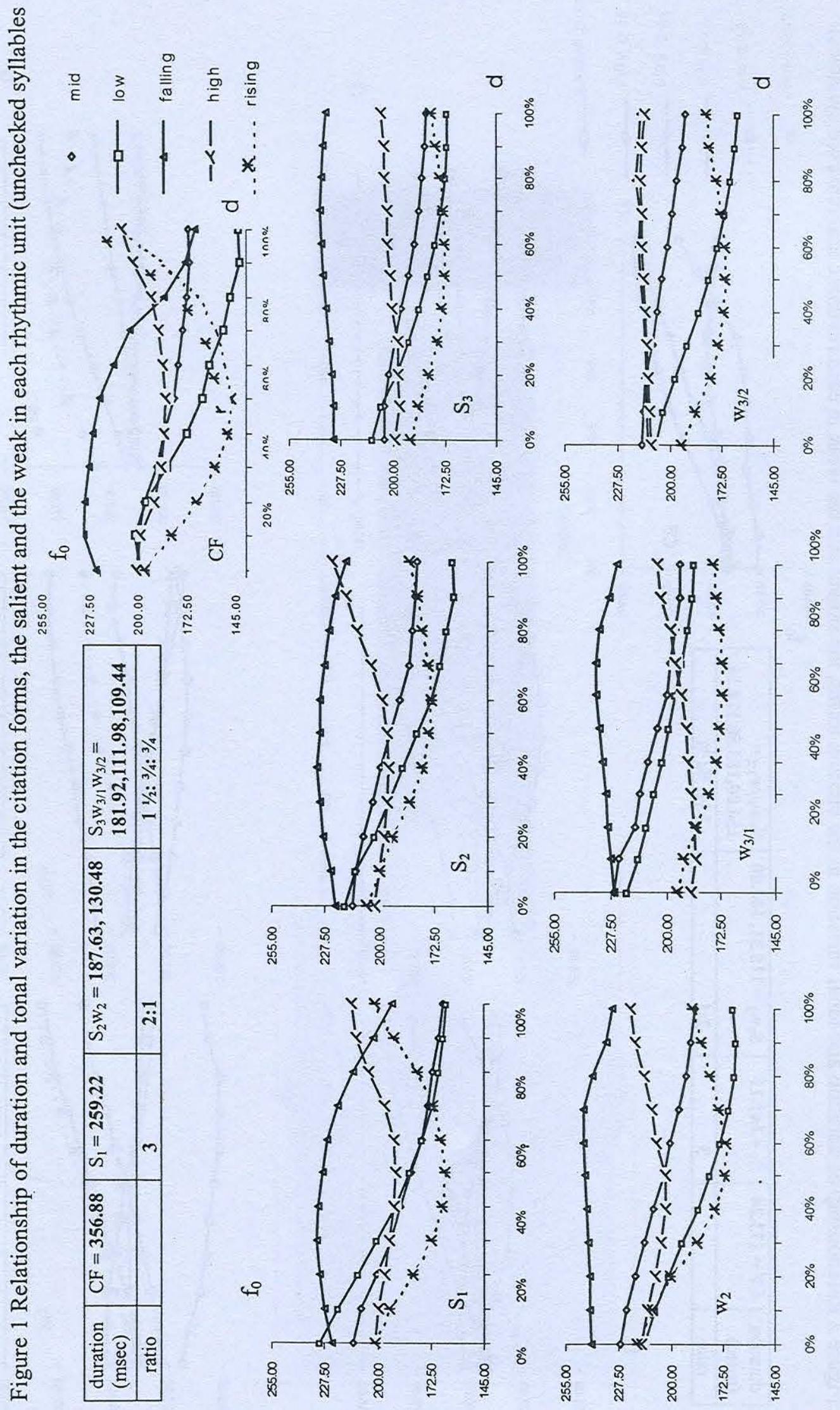



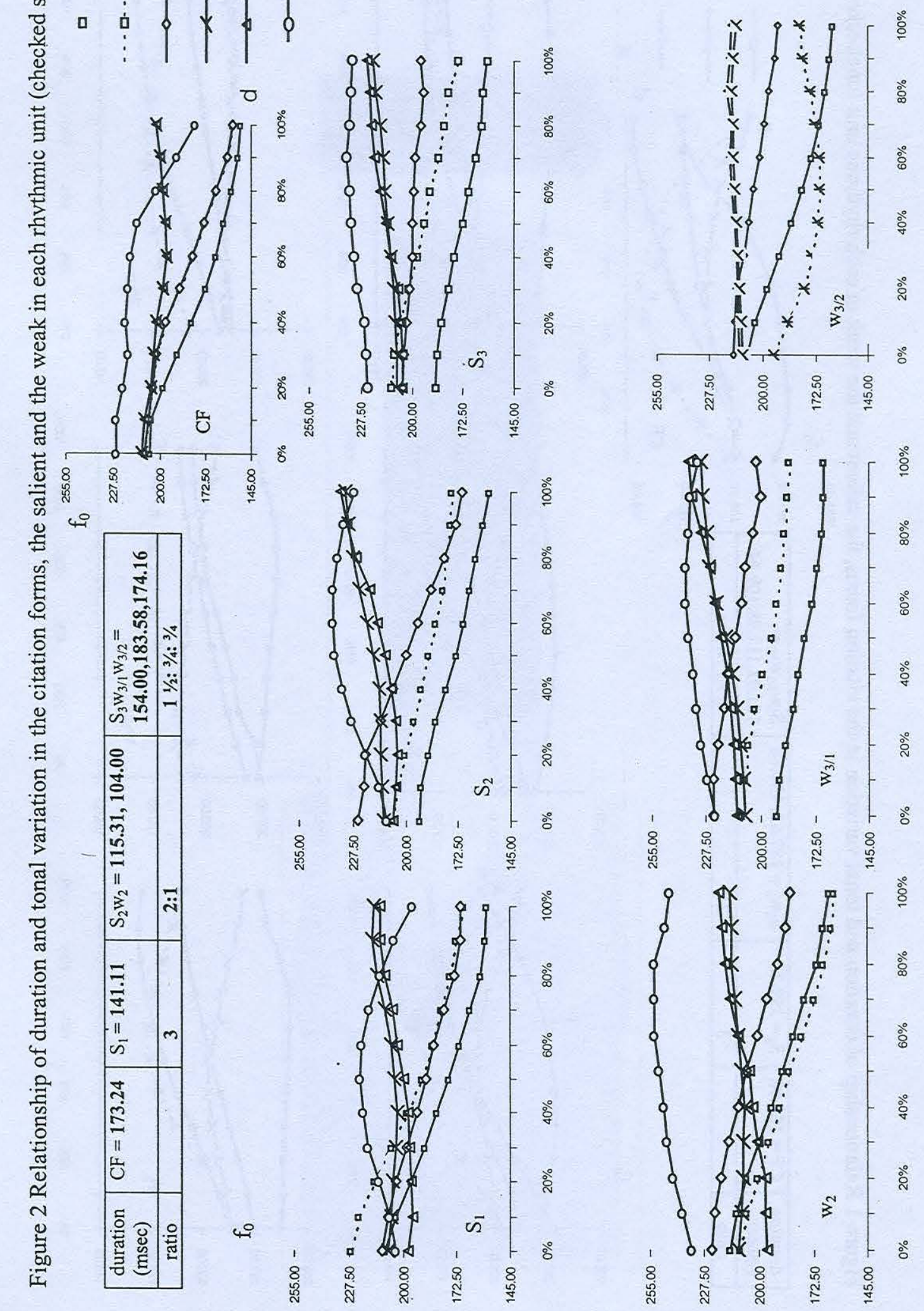
Table 1: The structure of the rhythmic units used in this study

\begin{tabular}{|l|l|l|}
\hline \multicolumn{2}{|l|}{ The structure of rhythmic units } & Symbol used \\
\hline one-syllable rhythmic unit & $|\mathrm{S}|$ & $\mathrm{S} 1$ \\
\cline { 2 - 3 } & $|\wedge|$ & - \\
\hline two-syllable rhythmic unit & $|\mathrm{Sw}|$ & $\mathrm{S} 2, \mathrm{w} 2$ \\
\cline { 2 - 3 } & $|\wedge \mathrm{w}|$ &,$- \mathrm{w} 2$ \\
\hline three-syllable rhythmic unit & $|\mathrm{Sww}|$ & $\mathrm{S} 3, \mathrm{w} 3 / 1, \mathrm{w} 3 / 2$ \\
\cline { 2 - 3 } & $|\wedge \mathrm{ww}|$ & $-, \mathrm{w} 3 / 1, \mathrm{w} 3 / 2$ \\
\hline
\end{tabular}


Table 2. Tonal realization in the salient and weak syllables in each rhythmic unit compared to the citation forms ${ }^{10}$

\begin{tabular}{|c|c|c|c|c|c|c|c|c|c|c|c|c|}
\hline \multirow[b]{4}{*}{ Contexts } & \multirow[t]{4}{*}{ tones } & \multicolumn{8}{|c|}{ Level } & \multicolumn{3}{|c|}{ contour } \\
\hline & & \multirow[t]{3}{*}{ Mid } & \multicolumn{4}{|c|}{ Low } & \multicolumn{3}{|c|}{ High } & \multicolumn{2}{|c|}{ Falling } & \multirow[t]{3}{*}{ rising } \\
\hline & & & \multirow[t]{2}{*}{ 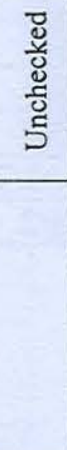 } & \multirow[t]{2}{*}{ 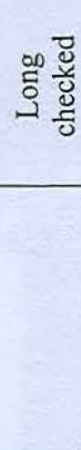 } & \multicolumn{2}{|r|}{ 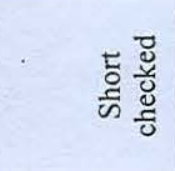 } & \multirow[t]{2}{*}{ 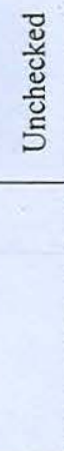 } & \multicolumn{2}{|r|}{ 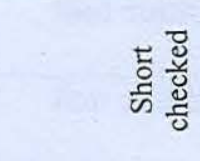 } & \multirow[t]{2}{*}{ 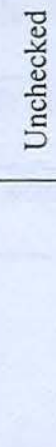 } & \multirow[t]{2}{*}{ 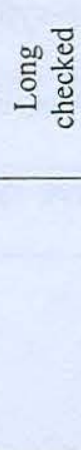 } & \\
\hline & & & & & 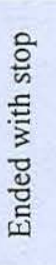 & 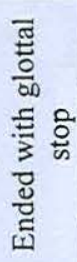 & & 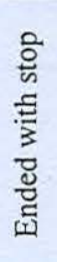 & 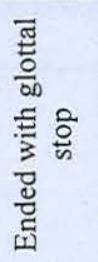 & & & \\
\hline \multirow{4}{*}{$\mathrm{S} 1 \sim \mathrm{CF}$} & Linear & $\mathrm{X}$ & $\mathrm{X}$ & $\mathrm{X}$ & $\sqrt{ }$ & $X$ & $x$ & $\sqrt{ }$ & $\sqrt{ }$ & $\sqrt{ }$ & $\sqrt{ }$ & $\mathrm{X}$ \\
\hline & Quadratic & $\mathrm{X}$ & $\mathrm{X}$ & $\mathrm{X}$ & $\mathrm{X}$ & $\sqrt{ }$ & $\sqrt{ }$ & $\mathrm{X}$ & $\mathrm{X}$ & $x$ & $\mathrm{X}$ & $\sqrt{ }$ \\
\hline & Pitch height & $\mathrm{X}$ & $\sqrt{ }$ & $\mathrm{X}$ & $\mathrm{X}$ & $\mathrm{X}$ & $\mathrm{X}$ & $\mathrm{X}$ & $\mathrm{X}$ & $\mathrm{X}$ & $\mathrm{X}$ & $\mathrm{X}$ \\
\hline & Conclusion & $\mathrm{X}$ & $\sqrt{ }$ & $\mathrm{X}$ & $\sqrt{ }$ & $\sqrt{ }$ & $\sqrt{ }$ & $\sqrt{ }$ & $\sqrt{ }$ & $\sqrt{ }$ & $\sqrt{ }$ & $\sqrt{ }$ \\
\hline \multirow{4}{*}{$\mathrm{S} 2 \sim \mathrm{CF}$} & Linear & $\mathrm{X}$ & $\mathrm{X}$ & $\sqrt{ }$ & $\sqrt{ }$ & $X$ & $\mathrm{X}$ & $\sqrt{ }$ & $\sqrt{ }$ & $\sqrt{ }$ & $\sqrt{ }$ & $\sqrt{ }$ \\
\hline & Quadratic & $\mathrm{X}$ & $\mathrm{X}$ & $\mathrm{X}$ & $\sqrt{ }$ & $\mathrm{X}$ & $\mathrm{X}$ & $\mathrm{X}$ & $\mathrm{X}$ & $\sqrt{ }$ & $\mathrm{X}$ & $\sqrt{ }$ \\
\hline & Pitch height & $\sqrt{ }$ & $\sqrt{ }$ & $\mathrm{X}$ & $\mathrm{X}$ & $\mathrm{X}$ & $\mathrm{X}$ & $\mathrm{X}$ & $\sqrt{ }$ & $\mathrm{X}$ & * & $\mathrm{X}$ \\
\hline & Conclusion & $\sqrt{ }$ & $\sqrt{ }$ & $\sqrt{ }$ & $\sqrt{ }$ & $X$ & $\mathrm{X}$ & $\sqrt{ }$ & $\sqrt{ }$ & $\sqrt{ }$ & $\sqrt{ }$ & $\sqrt{ }$ \\
\hline \multirow{4}{*}{$\mathrm{S} 3 \sim \mathrm{CF}$} & Linear & $\mathrm{X}$ & $\mathrm{X}$ & $\mathrm{X}$ & $\mathrm{X}$ & $\sqrt{ }$ & $\mathrm{X}$ & $\mathrm{X}$ & $\sqrt{ }$ & $\sqrt{ }$ & $\sqrt{ }$ & $\sqrt{ }$ \\
\hline & Quadratic & $\mathrm{X}$ & $\mathrm{X}$ & $\mathrm{X}$ & $\sqrt{ }$ & $\mathrm{X}$ & $\sqrt{ }$ & $\mathrm{X}$ & $\mathrm{X}$ & $\sqrt{ }$ & $\mathrm{X}$ & $\sqrt{ }$ \\
\hline & Pitch height & $\sqrt{ }$ & $\sqrt{ }$ & $\sqrt{ }$ & $\mathrm{X}$ & $\sqrt{ }$ & $\mathrm{X}$ & $\mathrm{X}$ & $\mathrm{X}$ & $\sqrt{ }$ & $\sqrt{ }$ & $\mathrm{X}$ \\
\hline & Conclusion & $\sqrt{ }$ & $\sqrt{ }$ & $\sqrt{ }$ & $\sqrt{ }$ & $\sqrt{ }$ & $\sqrt{ }$ & $\mathrm{X}$ & $\sqrt{ }$ & $\sqrt{ }$ & $\sqrt{ }$ & $\sqrt{ }$ \\
\hline \multirow{4}{*}{ w $2 \sim \mathrm{CF}$} & Linear & $\sqrt{ }$ & $\sqrt{ }$ & $\sqrt{ }$ & $\sqrt{ }$ & $\sqrt{ }$ & $\mathrm{X}$ & $\sqrt{ }$ & $\sqrt{ }$ & $\sqrt{ }$ & $\mathrm{X}$ & $\sqrt{ }$ \\
\hline & Quadratic & $\mathrm{X}$ & $\mathrm{X}$ & $\mathrm{X}$ & $\mathrm{X}$ & $\sqrt{ }$ & $\sqrt{ }$ & * & * & $\sqrt{ }$ & $\sqrt{ }$ & $\mathrm{X}$ \\
\hline & Pitch height & $\mathrm{X}$ & $\mathrm{X}$ & $\mathrm{X}$ & $\mathrm{X}$ & $\sqrt{ }$ & $\mathrm{X}$ & $X$ & $\mathrm{X}$ & $\mathrm{X}$ & $\mathrm{X}$ & $\mathrm{X}$ \\
\hline & Conclusion & $\sqrt{ }$ & $\sqrt{ }$ & $\sqrt{ }$ & $\sqrt{ }$ & $\sqrt{ }$ & $\sqrt{ }$ & $\sqrt{ }$ & $\sqrt{ }$ & $\sqrt{ }$ & $\sqrt{ }$ & $\sqrt{ }$ \\
\hline \multirow{4}{*}{ w $3 / 1 \sim \mathrm{CF}$} & Linear & $\mathrm{X}$ & $\sqrt{ }$ & $\sqrt{ }$ & $\sqrt{ }$ & $\sqrt{ }$ & $\mathrm{X}$ & $\sqrt{ }$ & $\sqrt{ }$ & $\sqrt{ }$ & $\sqrt{ }$ & $\sqrt{ }$ \\
\hline & Quadratic & $\mathrm{X}$ & $\mathrm{X}$ & $\mathrm{X}$ & $\sqrt{ }$ & $\mathrm{X}$ & $\sqrt{ }$ & $\mathrm{X}$ & $\mathrm{X}$ & $\sqrt{ }$ & $\mathrm{X}$ & $\mathrm{X}$ \\
\hline & Pitch height & $\sqrt{ }$ & $\sqrt{ }$ & $\mathrm{X}$ & $\mathrm{X}$ & $\sqrt{ }$ & $\mathrm{X}$ & $\sqrt{ }$ & $\sqrt{ }$ & $\mathrm{X}$ & $\sqrt{ }$ & $\mathrm{X}$ \\
\hline & Conclusion & $\sqrt{ }$ & $\sqrt{ }$ & $\sqrt{ }$ & $\sqrt{ }$ & $\sqrt{ }$ & $\checkmark$ & $\sqrt{ }$ & $\sqrt{ }$ & $\sqrt{ }$ & $\sqrt{ }$ & $\sqrt{ }$ \\
\hline \multirow{4}{*}{ w $3 / 2 \sim \mathrm{CF}$} & Linear & $\sqrt{ }$ & $\mathrm{X}$ & $\sqrt{ }$ & $\sqrt{ }$ & $\sqrt{ }$ & $\mathrm{X}$ & $x$ & $\sqrt{ }$ & $\sqrt{ }$ & $\sqrt{ }$ & $\sqrt{ }$ \\
\hline & Quadratic & $\sqrt{ }$ & $\mathrm{X}$ & $\sqrt{ }$ & $\sqrt{ }$ & $\sqrt{ }$ & $\sqrt{ }$ & $\sqrt{ }$ & $\mathrm{X}$ & $\sqrt{ }$ & $\mathrm{X}$ & $\mathrm{X}$ \\
\hline & Pitch height & $\mathrm{X}$ & $\mathrm{X}$ & $\downarrow$ & $\mathrm{X}$ & $\sqrt{ }$ & $\mathrm{X}$ & $\sqrt{ }$ & $\mathrm{X}$ & $\mathrm{X}$ & $\sqrt{ }$ & $\mathrm{X}$ \\
\hline & Conclusion & $\sqrt{ }$ & $\mathrm{X}$ & $\sqrt{ }$ & $\sqrt{ }$ & $\sqrt{ }$ & $\sqrt{ }$ & $\sqrt{ }$ & $\sqrt{ }$ & $\sqrt{ }$ & $\sqrt{ }$ & $\sqrt{ }$ \\
\hline
\end{tabular}

${ }^{10} \sqrt{ }=$ statistically significant

$\mathrm{X}=$ not statistically significant

* = probably statistically significant if more data 
Rhythmic Units and Tonal Variation in Thai

\begin{tabular}{|c|c|c|c|c|c|c|c|c|c|}
\hline \multicolumn{3}{|c|}{ рәурачว чвәW } & $\stackrel{\text { ¿ }}{=}$ & $\overline{\bar{\Xi}}$ & $\stackrel{\overline{\hat{n}}}{=}$ & $\begin{array}{l}8 \\
\dot{0} \\
\stackrel{0}{0}\end{array}$ & $\underset{\infty}{\infty}$ & $\aleph_{\infty}^{\infty}$ & $\frac{0}{\dot{z}}$ \\
\hline & \multicolumn{2}{|c|}{ рәуәәчәи Л иеәУ } & $\begin{array}{l}\infty \\
\infty \\
\infty \\
\infty\end{array}$ & สิ & $\underset{\infty}{\infty}$ & $\stackrel{\sigma}{\infty}$ & 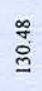 & $\stackrel{\infty}{\Xi}$ & 音 \\
\hline 营 & & & $\begin{array}{l}\tilde{\alpha} \\
\infty \\
0 \\
m\end{array}$ & $\hat{\tilde{a}}$ & $\begin{array}{c}\stackrel{\infty}{0} \\
\stackrel{\infty}{0}\end{array}$ & $\begin{array}{l}\stackrel{g}{\alpha} \\
\stackrel{\infty}{a}\end{array}$ & $\stackrel{\tilde{n}}{\underline{0}}$ & $\stackrel{\square}{\Xi}$ & ఏ్ \\
\hline \multirow{2}{*}{ 望 } & \multicolumn{2}{|c|}{ рәхрәчр 8иот } & 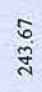 & 离 & $\frac{\hat{n}}{\underline{\sigma}}$ & $\begin{array}{l}8 \\
\check{z} \\
z\end{array}$ & $\stackrel{\hat{N}}{\cong}$ & $\bar{\Xi}$ & $\stackrel{\substack{\alpha \\
\cong}}{\cong}$ \\
\hline & \multicolumn{2}{|c|}{ рәурәуои } & 高 & 高 & ڤั่ & $\hat{\frac{\hat{N}}{2}}$ & $\frac{n}{0}$ & $\begin{array}{l} \pm \\
\dot{D} \\
\dot{\alpha}\end{array}$ & ڤू \\
\hline \multirow{3}{*}{ 高 } & \multirow[b]{2}{*}{ рахрәчо чочS } & 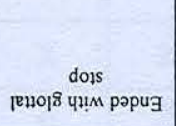 & $\begin{array}{l}\stackrel{+}{0} \\
\stackrel{0}{\underline{0}}\end{array}$ & $\begin{array}{l}\frac{\pi}{5} \\
\underline{0}\end{array}$ & $\stackrel{\infty}{\Xi}$ & $\stackrel{\tilde{\Xi}}{\varrho}$ & 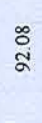 & $\frac{\infty}{8}$ & $\frac{7}{8}$ \\
\hline & & dois y!u papug & 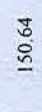 & $\stackrel{\infty}{\stackrel{\infty}{\Xi}}$ & ‡ँّ & $\stackrel{8}{\stackrel{8}{0}}$ & $\begin{array}{l}: \\
0 \\
\infty \\
0\end{array}$ & $\hat{\tilde{n}}$ & $\stackrel{\infty}{\circledR}$ \\
\hline & \multicolumn{2}{|c|}{ рәурәчэи } & $\begin{array}{l}\check{0} \\
\check{\sigma}\end{array}$ & $\frac{\text { ป }}{\mathfrak{d}}$ & 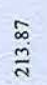 & $\stackrel{\widetilde{\Xi}}{\cong}$ & $\begin{array}{l}\hat{0} \\
\hat{\tilde{n}}\end{array}$ & $\stackrel{q}{\cong}$ & $\begin{array}{l}\text { aे } \\
\underline{\Xi}\end{array}$ \\
\hline \multirow{4}{*}{ 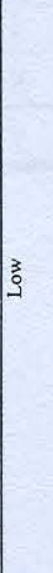 } & \multirow[b]{2}{*}{ рахрәчр дочS } & $\begin{array}{c}\text { dois } \\
\text { |eн요 4?!M papug }\end{array}$ & $\stackrel{\overbrace{}}{\Xi}$ & $\begin{array}{l}\hat{3} \\
\stackrel{0}{0}\end{array}$ & $\begin{array}{c}\kappa \\
\vdots \\
\sigma\end{array}$ & $\begin{array}{l}\text { ป } \\
\text { ปั) }\end{array}$ & $\frac{2}{8}$ & $\stackrel{\infty}{\vdots}$ & $\frac{1}{8}$ \\
\hline & & dois yiм рәрия & $\stackrel{\overbrace{}}{\Xi}$ & $\begin{array}{l}\text { ปี } \\
\cong\end{array}$ & 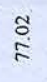 & $\begin{array}{l}\vdots \\
ٍ\end{array}$ & ऊิ & i̊ & สี \\
\hline & \multicolumn{2}{|c|}{ рәуэг्чр 8ио Т } & స్ & $\begin{array}{l}\stackrel{\infty}{0} \\
\underline{\hat{\sigma}}\end{array}$ & $\stackrel{\approx}{\check{\Xi}}$ & $\bar{\infty}$ & $\begin{array}{l}n \\
0 \\
\infty \\
\infty\end{array}$ & $\stackrel{\pi}{0}$ & $\begin{array}{c}\overline{0} \\
\infty\end{array}$ \\
\hline & \multicolumn{2}{|c|}{ рәхрәугип } & సे & $\hat{\stackrel{a}{0}}$ & $\stackrel{ \pm}{\underline{\Sigma}}$ & $\stackrel{\infty}{\stackrel{\infty}{\infty}}$ & $\hat{\tilde{o}}$ & $\begin{array}{l}\underset{T}{\sigma} \\
\stackrel{0}{O}\end{array}$ & $\stackrel{\tilde{N}}{\underline{\Xi}}$ \\
\hline 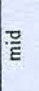 & & & = & $\frac{g}{\text { oे }}$ & $\stackrel{\infty}{\infty}$ & $\stackrel{\ddagger}{\cong}$ & 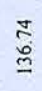 & 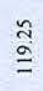 & E \\
\hline 递 & & 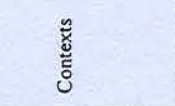 & 岕 & $\bar{s}$ & $\approx$ & $\approx$ & $\cong$ & ले & 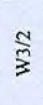 \\
\hline
\end{tabular}


Table 4. Tonal realization comparison of the salient syllables in each rhythmic unit

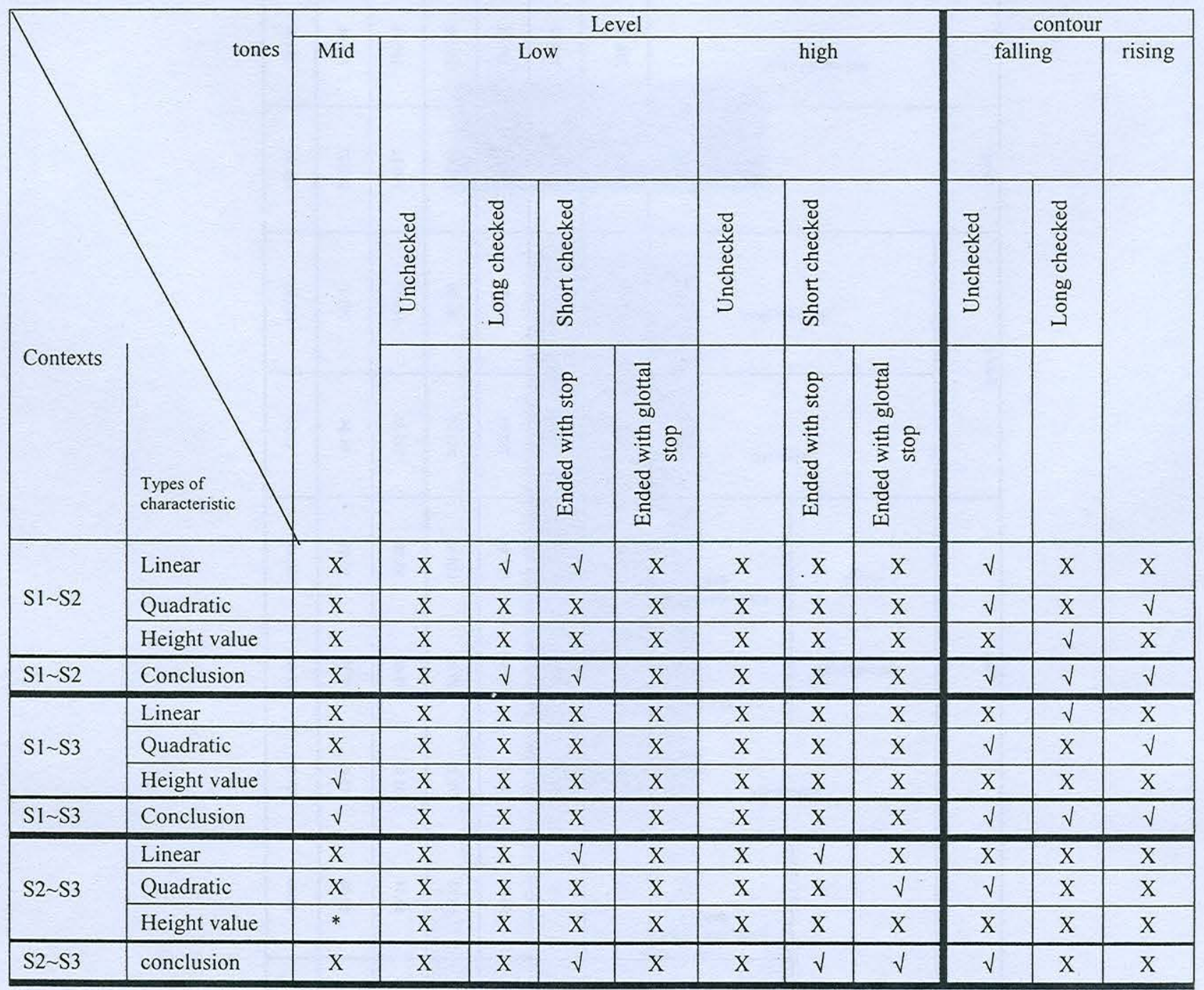


Table 4. Tonal realization comparison of the salient syllables in each rhythmic unit

\begin{tabular}{|c|c|c|c|c|c|c|c|c|c|c|c|c|}
\hline \multirow{2}{*}{\multicolumn{2}{|c|}{ tones }} & \multicolumn{8}{|c|}{ Level } & \multicolumn{3}{|c|}{ contour } \\
\hline & & \multirow{3}{*}{ Mid } & \multicolumn{4}{|c|}{ Low } & \multicolumn{3}{|c|}{ high } & \multicolumn{2}{|c|}{ falling } & \multirow{3}{*}{ rising } \\
\hline \multirow{2}{*}{ Contexts } & \multirow[b]{2}{*}{$\begin{array}{l}\text { Types of } \\
\text { characteristic }\end{array}$} & & \multirow[t]{2}{*}{ 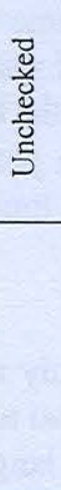 } & \multirow[t]{2}{*}{ 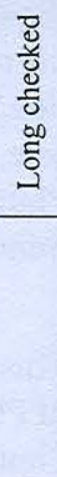 } & \multicolumn{2}{|c|}{ 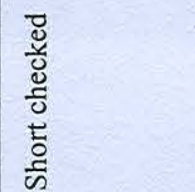 } & \multirow[t]{2}{*}{ 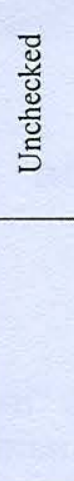 } & \multicolumn{2}{|l|}{ 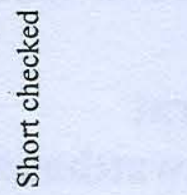 } & \multirow[t]{2}{*}{ 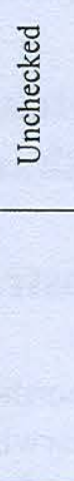 } & \multirow[t]{2}{*}{ 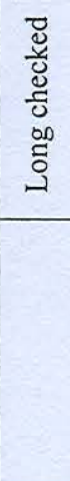 } & \\
\hline & & & & & 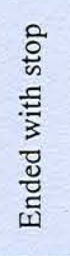 & 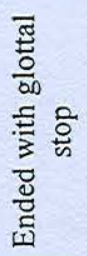 & & 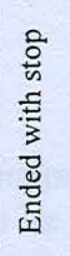 & 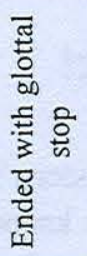 & & & \\
\hline \multirow{3}{*}{ S1 S2 } & Linear & $\mathrm{x}$ & $\mathrm{x}$ & $\sqrt{ }$ & $\checkmark$ & $\mathrm{x}$ & $\mathrm{x}$ & $\mathrm{x}$ & $\mathrm{x}$ & $\sqrt{ }$ & $\mathrm{x}$ & $\mathrm{x}$ \\
\hline & Quadratic & $\mathrm{X}$ & $\mathrm{x}$ & $\mathrm{x}$ & $\mathrm{x}$ & $\mathrm{X}$ & $\mathrm{X}$ & $\mathrm{x}$ & $\mathrm{X}$ & $\sqrt{ }$ & $\mathrm{x}$ & V \\
\hline & Height value & $\mathrm{x}$ & $\mathrm{X}$ & $\mathrm{x}$ & $\mathrm{x}$ & $\mathrm{x}$ & $\mathrm{X}$ & $\mathrm{x}$ & $\mathrm{x}$ & $\mathrm{x}$ & $\sqrt{ }$ & $\mathrm{x}$ \\
\hline S1 S2 & Conclusion & $\mathrm{X}$ & $\bar{x}$ & $\sqrt{ }$ & $\sqrt{ }$ & $\mathrm{x}$ & $\bar{x}$ & $\bar{x}$ & $\mathrm{x}$ & $\bar{v}$ & $\sqrt{ }$ & $\sqrt{ }$ \\
\hline \multirow{3}{*}{ S1 S3 } & Linear & $\mathrm{X}$ & $\mathrm{X}$ & $\mathrm{X}$ & $\mathrm{X}$ & $\mathrm{X}$ & $\mathrm{X}$ & $\mathrm{X}$ & $\mathrm{X}$ & $\mathrm{X}$ & $\sqrt{ }$ & $\mathrm{X}$ \\
\hline & Quadratic & $\mathrm{x}$ & $\mathrm{x}$ & $\mathrm{X}$ & $\mathrm{x}$ & $\mathrm{X}$ & $\mathrm{X}$ & $\mathrm{X}$ & $\mathrm{x}$ & $\sqrt{ }$ & $\mathrm{x}$ & $\checkmark$ \\
\hline & Height value & $\sqrt{ }$ & $\mathrm{x}$ & $\mathrm{x}$ & $\mathrm{x}$ & $\mathrm{X}$ & $\mathrm{X}$ & $\mathrm{X}$ & $\mathrm{x}$ & $\mathrm{X}$ & $\mathrm{x}$ & $\mathrm{x}$ \\
\hline S1 S3 & Conclusion & $\sqrt{ }$ & $\bar{x}$ & $\bar{x}$ & $\mathrm{x}$ & $\bar{x}$ & $\bar{x}$ & $\bar{x}$ & $\bar{x}$ & $\sqrt{ }$ & $\sqrt{ }$ & $\sqrt{ }$ \\
\hline \multirow{3}{*}{$\mathrm{S} 2 \sim \mathrm{S} 3$} & Linear & $\bar{x}$ & $\bar{x}$ & $\bar{x}$ & T & $\mathrm{X}$ & $\mathrm{X}$ & $\sqrt{ }$ & $\mathrm{X}$ & $\mathrm{x}$ & $\mathrm{X}$ & $\mathrm{x}$ \\
\hline & Quadratic & $\mathrm{X}$ & $\mathrm{x}$ & $\mathrm{x}$ & $\mathrm{X}$ & $\mathrm{X}$ & $\mathrm{X}$ & $\mathrm{X}$ & $\sqrt{ }$ & $\sqrt{ }$ & $\mathrm{x}$ & $\mathrm{x}$ \\
\hline & Height value & * & $\mathrm{x}$ & $\mathrm{x}$ & $\mathrm{x}$ & $\mathrm{x}$ & $\mathrm{x}$ & $\mathrm{x}$ & $\mathrm{x}$ & $\mathrm{x}$ & $\mathrm{x}$ & $\mathrm{x}$ \\
\hline S2 $\sim \mathrm{S} 3$ & conclusion & $\bar{x}$ & $\bar{x}$ & $\mathrm{x}$ & $\sqrt{ }$ & $\mathrm{x}$ & $\mathrm{x}$ & $\sqrt{ }$ & $\sqrt{ }$ & $\bar{v}$ & $x$ & $x$ \\
\hline
\end{tabular}

